\title{
Liderlighedens fædreland - Noter om pornografiens frigivelse og religionsspørgsmålet
}

Den hollandske kunsthistoriker Sven Lütticken har for nylig i sin bog om moderne ikonoklasme hævdet, at al magtfuld kritik historisk har stået i en form for dialog med religiøse billeder og forestillinger, mens den samtidig har forandret disse billeder og forestillinger (Lütticken 2009: 21). Ikonoklasme forstås således ikke blot som den fysiske destruktion af billeder, men også som en potentielt mere konstruktiv og kreativ forandring af forestillinger og ideer.

Billedpornografien kan anskues som en form for visuel seksualisme, en intens optagethed af billedliggørelsen af det seksuelle, der på interessant og kompleks vis forbinder sig med ikonoklasme, ikonofili og religion. Billedpornografiens skiftende kulturelle og juridiske status er intimt knyttet til religionens position i samfundet, ligesom man historisk kan iagttage, at pornografien har været anvendt i satirisk og parodisk øjemed over for religiøse autoriteter. I en dansk kontekst er sammenhængen mellem billedpornografiens frigivelse og en oplysningsbaseret religionskritik endda særdeles manifest, hvad kunsthistorien kan demonstrere. Hos en række danske billedkunstnere, mest eksplicit og medieberømmet hos Jens Jørgen Thorsen, bearbejdedes denne relation ligefrem aktivt og provokerende $\mathrm{i}$ værker og happenings, der tog afsæt i en kristen billedtradition. Pornografiens frigivelse i Danmark, der kan opfattes som ophævelsen af et signifikant billedforbud, er således langt fra entydigt sammenhængende med en ateistisk strømning i befolkningen eller en generel sekularisering. Derimod indskriver pornografiens legalisering sig i en mere kompleks kamp om seksualitetens status inden for kulturen generelt, men også inden for kristendommen.

To fotografiske tidsbilleder fra perioden kan demonstrere dette. Det første stammer fra 1969, hvor Det Ny Samfund havde arrangeret en demonstration for legalisering af hash på Christiansborg Slotsplads. Et reportagefoto viser den tætte mængde af langhårede, unge mennesker på pladsen. En af dem holder et håndskrevet skilt, hvor der med versaler står: "Jesus langt hår - Hitler og Thestrup kort hår" (Hansen et al.: 179). 
Det andet tidsbillede stammer fra 1973, hvor et kristent protestoptog mod Jens Jørgen Thorsens Jesusfilm bevægede sig gennem København fra Trianglen til Rådhuspladsen. Et fotografi viser medlemmer af Frelsens Hær, der holder et skilt med påskriften "Ingen skattepenge til Thorsen". I baggrunden holder en anden person et skilt, der er udformet som profilen af en gris, med ordlyden: "Svineriet begyndte med Thestrup" (Falbert 2006: 103). Jesus, Jens Jørgen Thorsen og Knud Thestrup - der fungerede som justitsminister fra 1968 til 1971 og dermed formelt var den, der ophævede forbuddet mod billedpornografi i 1969 - forbindes i disse tidsbilleder på intrikat vis. De 'langhårede' provoer i den revolutionære ungdomskultur lagde i 1969 beslag på Jesus, mens de tog afstand fra fascismen i skikkelse af Hitler, som de i et snuptag også associerede den siddende justitsminister med. De kulturbevarende kristne tog i 1973 afstand fra Jens Jørgen Thorsen, men også fra Knud Thestrup, som de associerede med 'svineriet', dvs. billedpornografien. Diskurserne omkring frigivelsen af pornografien var med andre ord del af en mere omfattende værdikamp, der trak tråde tilbage til større, ideologiske formationer i mellemkrigstiden, og desuden kan ses som forløbere for de aktuelle diskussioner omkring religion(er) og billedforbud.

\section{To argumenter for frigivelse af pornografi}

Startskuddet lød, da folketingspolitiker Else-Merete Ross fra Det Radikale Venstre den 25. november 1964 fremsatte spørgsmålet om ophævelse af straf for pornografi til justitsministeren i Folketingets spørgetid (Folketingstidende 1964-65: sp. 925). Den kvindepolitisk engagerede Ross, som i samme periode bl.a. kæmpede for homoseksuelles rettigheder, henviste til, at tiden var løbet fra lovgivningen, at det ikke kunne være straffelovens opgave at håndhæve moral med tvang og at staten ikke burde blande sig i voksne menneskers valg af lekture. Hendes hovedargument for spørgsmålet lød, at det var på tide, at "domstolene fritages for det hverv at skulle vogte moralen og bestemme, hvad voksne mennesker må læse og ikke må læse.” (Folketingstidende 1964-65: sp. 925). Det var en holdning, som Ross ikke var ene om at have, men tværtimod delte med en række opinionsmagere i tiden. Hun refererede da også til forskellige avisartikler og debatindlæg i motivationen af sit spørgsmål, ligesom hun i øvrigt nævnte en enkelt kunstner, Wilhelm Freddie, og retssagen imod ham, som et eksempel på, at retsinstanserne ikke havde haft held til at bevise de "skade- 
lige virkninger" af pornografien. Ross fremsatte desuden det synspunkt, at "det eneste effektive middel til begrænsning af såkaldt pornografi er ubemærkethed". (Folketingstidende 1964-65: sp. 925)

Som bekendt førte spørgsmålet til en ophævelse af straffen for pornografi i Danmark - først den litterære i 1967 og siden billedpornografien i 1969. De to dominerende synspunkter i Ross' opfordring til ophævelse af straffen for pornografi, ideen om moralens relativisering og individualisering samt ideen om repressionen som årsag til pornografiens eksistens, var langt fra nye. De blev allerede i 1928 fremsat med argumentatorisk prægnans af Poul Henningsen i artiklen "Pornografiens pædagogiske værdi". Med en behørig reference til Georg Brandes argumenterede Henningsen $i$ artiklen for en udvikling i retning af tiltagende frihed og - med afsæt i verserende debatter om Josephine Baker - en tendens til "en renere Opfattelse af [...] det nøgne Menneske - end før." (Henningsen 1928: 50). Med hensyn til den begrebslige sammenkobling af moral og pornografi argumenterede Henningsen, at

Langt smukkere vilde det være, om vi anerkendte Pornografien, som paa Forhaand moralsk ubestemt, og gennem Kritik, saaledes som vi udøver den paa andre Omraader, hvergang karakteriserede pornografiske Kunstværker som gode eller daarlige, moralske eller umoralske, alt efter Kritikernes Overbevisning (Henningsen 1928: 52).

Og med hensyn til spørgsmålet om pornografiens eksistens og udbredelse argumenterede han, at

Det er dens første pædagogiske Værdi, at den begaar Harikiri og indskrænker sit Omraade, og da dette Omraade altid er perifert i Kærlighedslivet, og kun opstaaet gennem dum Hemmelighedsfuldhed og Taburegler, gør den saaledes moralsk Nytte (Henningsen 1928: 52).

De samme to argumenter blev spidsformuleret i Inge og Steen Hegelers famøse og indflydelsesrige Karlighedens ABZ, der da den udkom i 1961 for alvor indvarslede et forandret syn på seksualitet og pornografi. Forfatterparret definerede i den leksikalske bog begrebet pornografi som "et skældsord for alle de ting, som støder os - som støder an mod vor kønsmoral på grund af deres sexuelle indhold" (Hegeler 1963: 192). Poul Henningsens harikiri-tese tilsluttede Hegeler-parret sig ligeledes, idet de hævdede, at "hvis det sexuelle behov hos den enkelte har vokset sig tilstrækkeligt stort, vil man se, at næsten alt kan virke sexuelt ophidsende, mens 
omvendt intet vil kunne virke ophidsende på den helt tilfredsstillede." (Hegeler 1963: 192). I dag, på mere end et halvt århundredes afstand, er det værd at minde om, at disse synspunkter om pornografi blev fremsat på et tidspunkt, hvor ideen om 'det pornografiske' primært blev næret gennem verserende retssager mod litterære produkter af anerkendte forfattere, mens den kvasi-anonyme og kommercielle pornografi fyldte langt mindre i diskussionerne.

\section{Emancipationens retorik}

Ross' spørgsmål førte til udarbejdelsen af en rapport fra Straffelovrådet om emnet, og på baggrund af dette arbejde, som var baseret på en række relevante ekspertudsagn, blev en ophævelse af straf for (den litterære) pornografi foreslået. Da strafophævelsen var blevet en realitet for både tekst- og billedpornografi i slutningen af 1960erne, kunne man iagttage at de samme to hovedargumenter blev overtaget af den konservative justitsminister Knud Thestrup. Efter Folketingets vedtagelse af frigivelsen af billedpornografien udtalte han således til Kristeligt Dagblad, at "det er en personlig frihed selv at kunne bestemme, om man vil købe pornobilleder eller ej" og at "pornobølgen er i aftagen, og jeg mener frigivelse af litteraturen har været stærkt medvirkende." (KD, 29. maj 1969). Og Politiken videregav samme dag et lignende synspunkt fra Thestrup, da de skrev at "Billedpornografien frigives fra 1. juli, hvorefter det ikke bliver nær så spændende at købe og studere fotografier af 'det'. Det mener i hvert fald både justitsministeren og det folketingsudvalg, der indstiller lovforslag nr. 152 til vedtagelse: pornografiske billeder m.v." (Politiken, den 29. maj 1969).

Argumentationen baserer sig på en rationalistisk purisme, der nærer en tillid til det oplyste og 'frigjorte' menneskes seksuelle sundhed. Nøgenheden applauderedes ikke blot i bogstavelig betydning, men også metaforisk, dvs. som en afklædning af irrationelle og religiøse dogmer, fordomme og tabuer. Som Henningsen på nykantiansk vis formulerede det: "Ungdommen har Evnen til at trænge ind til Kunstnydelsen bagom de Associationer, som for den ældre er pornografiske, ind til det man kalder 'det uinteresserede Behag” (Henningsen 1928: 50). Men frem for alt kan argumentationen ses som et opgør med en elitær normativitet, der dikterer den herskende klasses smag som gældende for alle. Nu skulle 'dårlig smag' med andre ord være et frit valg på linje med 'den gode smag'. Som histori- 
keren Morten Thing har formuleret det, så blev der dermed føjet et kulturrelativistisk perspektiv til frihedsdiskussionen, og i 1960erne var der efter årtier skabt grobund for en sådan kulturrelativisme (Thing 1999: 139).

Den seksuelle frigørelseskamp trækker især spor tilbage til mellemkrigstidens Danmark, hvor Kulturradikalismen og dens tro på antiautoritære, frie og oplysningsbaserede opdragelsesformer frembød en væsentlig modstand mod de nazistiske strømningers omvendte dyrkelse af en streng og autoritær kropsideologi. Emancipationsbestræbelserne manifesterede sig i 1930erne konkret i tidsskriftet Sex og Samfund, der med afsæt i bl.a. Wilhelm Reichs freudo-marxistiske ideer indskrev seksualiteten og dennes samfundsmæssige administration i et politisk register, idet der plæderedes for bl.a. fri adgang til svangerskabsforebyggelse og oplysninger om kønslivet. Sex og Samfund kom imidlertid selv til at danne ramme om flere retssager vedrørende pornografi, idet redaktionen i 1938 anklagedes efter Straffelovens paragraf 234 om udbredelse af "utugtige skrifter, billeder eller genstande" (Elbrønd-Bek og Ravn 1975: 13).

Da Sex og Samfund som reaktion på anklagen lavede en enquete om pornografispørgsmålet, udtrykte forfatteren Peter Freuchen den samme holdning, som i forskellige varianter kendetegnede den kulturradikale position igennem de følgende mange år:

Jeg tror bestemt, at hvis alle sexuelle spørgsmål var aabne og drøftedes frit, saa vilde det 'interessante' og forborgne snart forsvinde. Der vilde ingen 'pornografi' findes. Mørkemændene vilde sultes ihjel. Markedet for utugtige billeder vilde forsvinde, for de gør dog vist kun forretning mellem mennesker i trang (Elbrønd-Bek og Ravn 1975: 86).

Spekulation i sanselighed skulle således være motiveret alene af hemmelighedskræmmeriet omkring det seksuelle. Eftertiden har som bekendt dementeret dette eftertrykkeligt, for så vidt som spekulationen eksisterer i bedste velgående, selv om enhver mulig hemmelighed på det seksuelle område må betragtes som afsløret i det Jean Baudrillard har kaldt pornografiens "orgie af realisme" (Baudrillard 1985: 38). Som det er fremgået, lå forestillingen om en uskyldsren essens, der via driftsundertrykkelse ødelægges og perverteres, imidlertid til grund for emancipationsbestræbelserne langt op i efterkrigstiden. Det var denne ide, der fik Herbert Marcuse til i bogen Eros og civilisation fra 1955 kritisk at gentænke Freuds oprindelige tese om en nødvendig civilisatorisk konflikt mellem lystprincippet og realitetsprincippet. I bogen spurgte Marcuse bl.a., om ikke man kunne 
"forestille sig en ikke-repressiv civilisation, hvilende på et fundamentalt anderledes forhold mellem mennesket og naturen og fundamentalt anderledes eksistentielle relationer" (Marcuse 1980: 22). Hans spørgsmål blev indoptaget af ikke mindst ungdomskulturen i 1960erne, der omsatte det fra en filosofisk undersøgelse til et konkret handlingsprogram med en række vidtgående livsformseksperimenter, der forsøgte at aflægge sig driftsundertrykkelsens hæmmende indflydelse. Det er derfor ikke overraskende, at fx Morten Thing - men også en fremtrædende amerikansk forsker som Walter Kendrick (1987) - med pornografiens frigivelse taler om en kulturhistorisk afslutning af "forbudets epoke" (Thing 1999: 8) og "afslutningen på tugten" (Thing 1999: 138). Strafophævelsen for pornografi ses således af Thing som kulminationen på oplysningens og frihedens triumfer op igennem det 20. århundrede, og Michel Foucaults tese om den emancipatoriske seksualdiskurs' egen magtudøvelse i form af påbud frem for forbud bliver problematiseret (Thing 1999: 16).

Om repression afløstes af emancipation eller om den blot blev erstattet af nye påbud er en omfattende diskussion. Det er imidlertid klart, at et nyt paradigme for seksuel sundhed som synonymt med tilfredsstillelse og behovs- og begærsindfrielse trådte i kraft med massiv styrke i løbet af 1960 erne - ikke mindst i forhold til førægteskabelige relationer. Som bl.a. kritik fra feministisk hold har påpeget, blev kønsforskelle og forskelle i seksuel orientering ikke indtænkt i forbindelse med disse forandringer, som derimod implicit rummede et påbud om en maskulin og heteroseksuel behovs- og begærsindfrielse (Højgaard Cawood og Sørensen 2004: 223). Bente Hansen, der selv var part i ungdomsoprøret, har beskrevet, hvordan det først med kvindebevægelsen i begyndelsen af 1970erne blev et mere påtrængende spørgsmål, "hvem der var blevet frigjort og hvem der havde fået fordel af det” (Hansen et al. 1978: 242). Potentielle konflikter og interesseforskelle mellem et spektrum af behov og begær var i mindre grad et emne på dette tidspunkt, hvor en heteroseksuel maskulin norm uproblematiseret dominerede. Emancipationen foregik på mændenes betingelser og konfliktzonen var ikke defineret inden for rammerne af køn og seksuel orientering, men snarere i forhold til et politisk og religiøst felt. 


\section{Fra seksualmoral til seksualpolitik}

Den kendsgerning at Kristeligt Folkeparti i 1970 blev oprettet som en direkte følge af ophævelsen af forbuddet mod pornografien, vidner tydeligt om, at såvel seksualitet som religion i denne periode politiseredes på nye måder og at der måske nok var en generel accept af pornografiens frigivelse, men ikke nogen ublandet konsensus. Seksualmoral blev udhævet af den religiøse forankring for i stigende grad at blive til en sekulariseret seksualpolitik, og som en modstrategi blev religionen også gjort til et politisk anliggende. En af Kristeligt Folkepartis stiftere, pastor Niels Erik Rosendal, advarede således i forbindelse med udsigten til frigivelsen af billedpornografien i 1969 om en "bevidst afkristning" af det danske folk fra den siddende VKR-regerings side, og hans centrale argument var netop den nye opfattelse af pornografien. I et åbent brev i Kristeligt Dagblad adresseret til det konservative folketingsmedlem Ole Vestergaard Poulsen skrev Rosendal:

Det konservative Folkepartis formand har - med Deres udtrykkelige og ensomme protest - givet grønt lys for karakter- og moralnedbrydende pornosvineri af hidtil ukendte dimensioner. Det fineste og reneste i menneskelivet, forholdet mellem mand og kvinde, besudles med statslig autorisation. (KD, 21. maj 1969)

Da stiftelsen af Kristeligt Folkeparti kort tid senere tegnede sig som en reel mulighed, argumenterede Rosendal atter for 'pornolovens' centrale status i denne henseende, for "den vil nemlig få særdeles vidtrækkende konsekvenser for det danske folks moralske standard, som - efter hvad udlændinge siger - i forvejen ikke er rosværdig." (KD, 7.-8. juni 1969). Modstanden mod frigivelsen af pornografien kom næsten helt entydigt fra religiøst hold i 1960erne, mens fortalerne omvendt var at finde blandt kulturradikale og kunstnere, for hvem frigivelsen af pornografien var en del af en mere omfattende emancipationskamp og en kamp for ytringsfrihed. Seksualitetens 'frigørelse' var i høj grad synonym med en udhævelse af dens forankring i en holistisk og konservativ kristen livsforståelse, hvor den var ufravigeligt bundet til den biologiske reproduktion inden for rammerne af det heteroseksuelle ægteskab. Kriminologen Berl Kutchinsky har ligefrem hævdet, at den primære årsag til at pornografien kunne frigives i Danmark i 1960erne, var opgøret med tabuet over for onani, der som bekendt også er - gammeltestamentligt - kristent (Kutchinsky 1999: 5657). Seksualitetens tiltagende autonomisering, som pornografien sammen 
med nye præventionsmidler, især p-pillen, og forandrede samlivsmønstre eksplicit manifesterede, kan således ses som en slækkelse af den intime sammenhæng mellem statsmagt og religion, dvs. en reduktion af statsreligionens politiske indflydelsessfære. Medicinske, ideologiske, økonomiske, sociale og moralske forandringer samarbejdede således om at udsætte det Marcuse kaldte "den monogam-patriarkalske familie" for et stigende pres (Marcuse 1980: 45). Alternative og eksperimenterende eksistens- og samlivsformer voksede frem på denne baggrund, ligesom kønsrollerne undergik forandringer. Det er netop i dette lys, man må forstå Rosendals udfald mod den statslige autorisation af 'pornosvineriet' og den senere dannelse af Kristeligt Folkeparti. Pornografien blev set som en regulær krigserklæring mod det kristne livsgrundlag, hvilket næppe var nogen fejltolkning, selv om der snarere end 'afkristning' af den danske befolkning var tale om en 'omkristning', dvs. et forsøg på - revolutionært - at redefinere seksualitetens rolle inden for den kristne etik.

\section{Verdens første pornomesse}

Billedpornografien havde eksisteret som en legal udtryksform i knap fire måneder, da Jens Jørgen Thorsen i oktober 1969 holdt åbningstalen ved verdens første pornomesse, Sex 69, i K.B. Hallen. Ikke overraskende var hans tale derfor også formet som en hyldest til den nyvundne frihed fra censur:

For første gang i jordens udvikling er det blevet muligt uden frygt for forfølgelse, fængsling, forbandelse, forvisning, at tale om, at spille om, at digte $o g$ at synge om menneskehedens største drivkraft, fornøjelse, galskab, poesi, ja selve menneskehedens forudsætning: Det erotiske liv. (Thorsen 1980: 91)

Han opfordrede det talstærkt fremmødte publikum, hvoraf mange var kommet fra udlandet, til at sætte pris på denne frihed og "få den til at vokse som en værdifuld blomst", mens han i samme åndedrag fremhævede friheden som et enestående værn imod henholdsvis russisk og amerikansk kulturimperialisme (Thorsen 1980: 91). USAs tendens til "kommercialisering i røv og hoved" stillede Thorsen sig kritisk over for (Thorsen 1980: 91). Det kan synes ironisk, for så vidt som talen blev holdt midt $\mathrm{i}$ et kommercielt mekka, hvor en perlerække af pionersjæle udi pornoindustrien havde lejet sig ind i messestande, der solgte blade, film og andre produkter fra sexindustrien. Ambivalensen over for den begivenhed, han 
deltog i, kom da også til udtryk i den happening, som Thorsen udførte i forlængelse af sin tale. Her klatmalede han direkte på et par nøgne kvinder under ledsagelse af musik fra Papa Bues Viking Jazzband, mens han - givetvis til ære for det internationale publikum og den fremmødte verdenspresse - paraderede håndskrevne skilte med engelsksprogede ordlyde som "Down with censorship", "Pornography is dead" og "Do it yourself. Make your own pornography". I tråd med situationisternes interventionistiske strategier, som Thorsen så sig som Skandinavisk repræsentant for, kan denne happening betragtes som et ikonoklastisk detournement, der inden for sexindustriens egen logik peger på alternative handlemåder med vægt på aktiv deltagelse frem for passiv konsumption. Som Thorsen havde formuleret allerede i 1963, var 'publikum' en kategori, der skulle afskaffes "ved at gøre publikum medskabende", for "at gøre et menneske til tilskuer er at klippe nosserne af ham" (Nash og Thorsen 1963: 9). Man må således antage, at Thorsens hyldest ved åbningen af Sex 69 mindre angik pornografien som kulturindustrielt produkt end seksualitetens frisættelse. Hvis det endelig skulle være en hyldest til pornografien, var det i dens kunstneriske snarere end dens rent kommercielle varianter, hvilket referencerne til navne som Henry Miller, Rabelais og de Sade i åbningstalen vidner om.

Hos kunstnere som disse fungerede fremstillingen af seksualiteten som et slags revolutionært våben, der kunne tages i brug i bekrigelsen af den gældende seksualmoral, akkurat ligesom den gjorde det hos surrealisten Wilhelm Freddie, som Thorsen mere end nogen anden bekendte sit temperamentsmæssige hvis ikke stilistiske, slægtskab med. I et hyldestskrift til Freddie nævner Thorsen således at de to har betrådt "de erotiske slagmarkers usynlige linier" sammen i "liderlighedens fædreland", hvor de angiveligt mødte hinanden (Thorsen 1982: sine pagina). I en anden sammenhæng hævder Thorsen, at Freddie med sine radikale skandaleværker fra 1920erne og 1930erne foregreb 1960ernes emancipationskamp, og at frifindelsen af Freddie som udgangen på retssagen mod ham i 1963 var selve den begivenhed, der "medførte en fuldstændig ophævelse af censuren i Danmark" (Thorsen 1982: 103). Sandt er det, at Freddie ifølge myndighederne havde gjort sig skyldig i 'erotomani', som var 1930ernes betegnelse for seksualisme, men at han også senere - i 1960erne, da erotomanien blev omsat til en kulturel bevægelse i skikkelse af den seksuelle revolution - blev taget til nåde. Thing refererer politiet for i 1937 at betegne Freddie som en "Erotoman", der med sine værker "vil forelægge Beskueren en 'Kryds- og Tværs-Opgave, hvis Løsning er, at Livet er en Ørken, 
i hvilken Menneskene klumper sig sammen og at alt drejer sig om Erotik" (Thing 1999: 96). Selv om Freddies skandaleværker fra 1930erne ikke var blasfemiske, for så vidt som de i overvejende grad slet ikke indeholdt religiøse referencer (på nær malerier som Satanisk elskov fra 1936 og Bon fra 1940), er det ikke desto mindre sandsynligt, at det netop var aktivistiske kristne pressionsgruppers generelle indflydelse i 1930erne, som sammen med nazismens afsmag for kunstneriske avantgardestrømninger gav anledning til at kende dem utugtige og anstødelige. Som Thing har påvist, var 1930erne netop det årti, hvor der fandt flest domfældelser sted med baggrund i straffelovens pornografiparagraf, paragraf 234, idet højretendenser og kristne grupperinger øvede stor indflydelse på kulturelle spørgsmål (Thing 1999: 64). Det utugtige var således i sig selv en udfordring for visse kristne kræfter i Danmark, selv om det ikke artikuleredes manifest blasfemisk, og måske af samme grund opfattedes pornografien per se som en drivkraft i afkristningen af den danske befolkning.

\section{Seksualisering af Kristusfiguren}

I så fald tog Thorsen på adækvat vis arven efter Freddie op, da han i begyndelsen af 1970erne i tiltagende grad begyndte at bearbejde religionsspørgsmålet i direkte sammenhæng med seksualitetsspørgsmålet. For Jesus var, som Bent Falbert bemærker i sin biografi om Thorsen, en "besættelse" for kunstneren, ligesom Thorsen nærede en "altopslugende fascination af sex" (Falbert 2006: 48, 99). Matricen til Thorsens sammenføring af kristendom og seksualitet kunne allerede iagttages på forsiden af tidsskriftet Aspekt, da det i december 1963 udkom med en collage forestillende en korsfæstet julenisse med en kanon som en peniserstatning. "Den kontrollerede jul. Gud, tradition, hygge" udsiger udklipsbogstaver henover collagen. Da Thorsen sammen med Jørgen Nash i sommeren 1965 arrangerede en demonstration på Strøget i København for kunstnerisk ytringsfrihed, promenerede den svenske kunstner Carl Magnus forrest med et assemblageskilt om halsen, der sagde "Den kunstneriske ytringsfrihed har ingen moralske grænser". På skiltet svævede øverst et billede af en fisk, et ikonografisk symbol på Kristus, og neden under strittede en tredimensional, erigeret penis frem af skiltet (Thorsen 1980: 15).

Denne tematik blev forenklet og skærpet, da Thorsen, efter sin store, internationale succes med filmatiseringen i 1970 af Henry Millers roman Quiet Days in Clichy, i 1972 bebudede, at han havde til hensigt at filmatisere 
Jesu Kristi kærlighedsliv. Filmen blev først - i modificeret form - realiseret i 1992 under titlen The Return, men i 1975 udgav Thorsen manuskriptet til filmen, som på det tidspunkt havde titlen The Love Affairs of Jesus Christ (Thorsen 1975). Alene annonceringen af intentionen om at lave en film, der omhandlede Jesu sexliv, var imidlertid tilstrækkeligt til at skabe international skandale omkring Thorsen. På dansk grund fulgte Thorsen ved adskillige lejligheder op på skandalen, mest spektakulært i det visuelle koncentrat af sin filmiske intention, som han leverede i form af et murmaleri $i$ Birkerød i oktober 1984. Her viste Thorsen den korsfæstede Kristus med erigeret lem, hvilket kan ses som en infantil og emblematisk fremstilling af ideen om Kristus som Guds søn, men samtidig et menneske med seksuelle impulser. Udførelsen blev forsætligt foretaget som toiletvæggens stiliserede graffitiæstetik, der blev forstørret til murmaleri i et offentligt rum.

Selvsagt kan ideen om at fremstille Jesus som et menneske med seksuelle impulser opfattes som blasfemisk, hvad den i allerhøjeste grad blev både $\mathrm{i}$ forbindelse med Thorsens filmplaner og hans murmaleri. Det var imidlertid i højere grad de katolske dele af Europa, herunder ikke overraskende i særdeleshed Vatikanet, der fordømte Thorsens filmplaner, end det var danske kristne. Ekstreme reaktioner som fx angreb på danske ambassader i Spanien og Italien bringer mindelser om den internationale krise, der blev konsekvensen af Jyllands-Postens karrikaturtegninger af Muhammed i 2005. At intentionen fra Thorsens side var blasfemisk, skal der ikke herske tvivl. Allerede i 1972 havde Thorsen i en kronik i Information lovprist denne strategi under overskriften "Længe leve blasfemien". Kronikken afsluttes med et citat af anarkisten Bakunin: "Blasfemien er den eneste vej til den sande religion: Tankens, hjertets, handlingens og frihedens" (Thorsen 1980: 115). Lovprisningen af blasfemien er imidlertid ikke synonym med en besyngelse af ateismen eller åndløsheden. Thorsens besættelse af Jesus vidner om en optagethed ikke blot af kirkens institutionelle administration af kristendommen, som Thorsen nok var kritisk over for, men også for Jesus som en rebelsk skikkelse, der selv satte sig op imod religiøse autoriteter med sit kristne frihedsbudskab. Ikke uden grund påberåbte Thorsen sig Søren Kierkegaard som allieret blasfemiker i en senere kronik, hvori han citerede Kierkegaard for sin forhånelse i Oieblikket nr. 9 fra 1855 af "nederdrægtige præsteløgne," der anstiller kristendommen som beroligende "i stedet for, at den i dybeste grund er opvakkende, uroligende" (Thorsen 1980: 107). At Kristusskikkelsens seksuelle implikationer i moderne tid har været tabuiserede og oversete demonstrerede 
kunsthistorikeren Leo Steinberg i øvrigt i de samme år i sin bog The Sexuality of Christ in Renaissance Art and in Modern Oblivion fra 1983, der påviste en righoldig førmoderne tradition for at tematisere seksualiteten inden for kristendommens egen ikonografi.

\section{Religionskritik og kunst}

Pornografiens frigivelse fletter sig i en dansk sammenhæng tæt sammen med en række billedkunstneres kritiske bearbejdelser af seksualitet, ritualitet og religion. Ungdomsoprørets generelle besyngelse af rebelsk strid mærkes tydeligt i periodens kunst, men en række kunstneres 'stride billeder' med fokus på religion og seksualitet lader sig ikke udtømmende forklare hermed. Ud over Thorsens værker kan Lene Adler Petersen og Bjørn Nørgaards undersøgelser af den kvindelige Kristusfigur fra samme periode nævnes, ligesom Richard Winthers mangeårige optagethed af kristendommens seksualitetsforståelse fremstår helt centrale. Alle disse kunstnere bearbejdede kritisk og provokerende seksualitetens rolle inden for kristendommen og de gjorde det med æstetiske virkemidler, der grænsede tæt op af det pornografiske. Som Thorsens eksempel viste, omfattede de billedpornografien med en dyb ambivalens, for så vidt som de påskønnede muligheden for at ytre sig frit om seksuelle anliggender, men var skeptiske over for kommercielle og stereotype aspekter af pornografien. Den nyvundne ytringsfrihed blev i de tidlige år efter frigivelsen anvendt til at udøve en historisk set unik form for kritik, en tvetydig ikonoklasme, af kristendommens forvaltning af seksualiteten - et aspekt som siden hen tilsyneladende er forsvundet ud af billedet.

Man kan spørge, hvorfor pornografien og dens religionskritiske potentialitet forsvinder som et anliggende for billedkunstnere i årene der følger. Uden at komme med en udtømmende forklaring, vil jeg foreslå følgende fire bud. For det første var pornografien i 1960'erne og begyndelsen af 1970'erne var interessant for billedkunstnere som en stilistisk markør for transgression, men i høj grad ophørte med at fungere som sådan med ophævelsen af forbuddet mod den. Pornografiens status som religionskritisk og blasfemisk ændrede sig også, da den med Linda Williams’ ord gik fra at være 'ob/scene' til at være 'on/scene' (Williams 2004: 3). Man kan med Lüttickens begreber sige, at pornografien hermed skiftede status fra at rumme en ikonoklastisk provokationskraft til gnidningsløst at tilfredsstille en ikonofili. For det andet, har Lisa Z. Sigel f. eks bemærket, at den 
kommercielle pornografis kolossale succes, masseudbredelse og normative effekt meget hurtigt forvandlede repræsentationen af seksualitet fra et åbent og eksperimenterende anliggende til en stereotyp og sexistisk købmandsforretning, hvor den associerede repression snarere end emancipation, og hvor den disciplinerende patriarkalske og heteronormative faktor blev genstand for gennemgribende kritik fra ikke mindst feministisk hold (Sigel 2005: 16). Som det tredje, kan det nævnes, at pornografien måske slet ikke er forsvundet som en subversiv, kunstnerisk genre, men derimod - som bl.a. Tim Stüttgen har argumenteret for (2006) - har forskudt sig til et DIY-plan i undergrundsmiljøer, hvor pornografiens begærs- og blikøkonomi, hele dens identitets- og repræsentationspolitiske dimension, udfordres via 'alternative' og anti-kommercielle seksualiteter. At billedkunsten i Danmark også fortsat tematiserer seksualitet, men nu snarere som et identitetspolitisk end et religionskritisk projekt, kan man iagttage hos samtidskunstnere som fx High Heel Sisters, Jørgen Callesen, Ingen Frygt, Gritt Uldall-Jessen, Peter Brandt og Signa. Endeligt kan det som det fjerde punkt nævnes, at bevægelsen fra et monokulturelt samfund til et stadig mere kulturelt, etnisk og religiøst sammensat samfund- sammen med globaliseringstendenserne - har gjort realiseringen af kulturradikalismens rationalistiske ideal problematisk, konfliktfyldt og politisk tvetydigt, hvilket Muhammed-krisen i kølvandet af Jyllands-Postens publicering af karikaturtegningerne af profeten Muhammed demonstrerede med al tydelighed. Ytringsfriheden og det danske frisind er med andre ord i dag blevet komponenter i en ideologisk magtkamp, hvor kortene er mere blandede end nogensinde tidligere, og hvor religionskritik sjældnere vedrører Kristendommen end Islam. 


\section{Litteratur:}

Baudrillard, Jean (1985 [1979]): Forforelse, Århus: Sjakalens Beduinserie.

Elbrønd-Bek, Bo \& Ravn, Ole (1975): '‘Sex og Samfund' - medarbejdere, historie, ideologi", in: Sex og Samfund. En antologi af artikler, noveller og digte fra tidsskriftets 4 argange, København: Fremad, s. 7-25.

Falbert, Bent (2006): Provo, København: Politikens Forlag.

Folketingstidende 1964-65.

Hansen, Bente; Jesper Høm; Gregers Nielsen; Roald Pay \& Jørgen Schytte (red.): Dengang i 60'erne - billeder fra dengang, tekster fra $i$ dag, København: Informations Forlag.

Hegeler, Inge og Steen (1963 [1961]): Karlighedens ABZ, 2. rev. udg., København: Chr. Erichsens Forlag.

Henningsen, Poul (1928): "Pornografiens pædagogiske Værdi", Kritisk Revy, hefte 2, juli 1928, s. 48-52.

Højgaard Cawood, Sarah \& Anette Dina Sørensen (2004): "Pornoens legalisering. Seksualitetens befrielse og kvinders seksuelle frigørelse?", in: Morten Bendix Andersen \& Niklas Olsen (red.): 1968 - dengang og nu, København: Museum Tusculanums Forlag, s. 211-235.

Kendrick, Walter (1987): The Secret Museum: Pornography in Modern Culture, New York: Viking.

Kutchinsky, Berl (1999): Law, Pornography and Crime: The Danish Experience, Oslo: Pax Forlag.

Lütticken, Sven (2009): Idols of the Market: Modern Iconoclasm and the Fundamentalist Spectacle, New York: Sternberg Press.

Marcuse, Herbert 1980 [1956]: Eros og civilisation. En filosofisk. Freud-undersogelse, København: Gyldendals Uglebøger.

Nash, Jørgen \& Jens Jørgen Thorsen (1963): "Co-ritus - interview med situationisterne: jørgen nash og jens jørgen thorsen", in: Aspekt - tidsskrift for politik og kultur, nr. 4, s. 7- 9.

Sigel, Lisa Z. (2005): "Introduction. Issues and Problems in the History of Pornography", in: Lisa Z. Sigel (red.): International Exposure: Perspectives on Modern European Pornography 1800-2000, Chapel Hill, NC: Rutgers University Press, pp. 1-26.

Steinberg, L. (1983). The sexuality of Christ in Renaissance art and in modern oblivion. New York: Pantheon Books.

Stüttgen, Tim (2006): "Zehn Fragmente zu einer Kartografie Postpornografischer Politiken", in: Texte zur Kunst, 16. Jahrgang, Heft 64, pp. 58-65.

Thing, Morten (1999): Pornografiens historie i Danmark, København: Aschehoug.

Thorsen, Jens Jørgen (1975): Thorsens Jesusfilm, København: Borgen.

Thorsen, Jens Jørgen (1980): Friheden er ikke til salg, København: Bogan.

Thorsen, Jens Jørgen (1982): Brandende blade, Rungsted Kyst: Internationalt Forlag.

Williams, Linda (2004): Porn Studies, Durham: Duke University Press. 
Avisartikler:

Blich- (signatur): "Pornobilleder bliver fri i handlen fra 1. juli", Kristeligt Dagblad, 29. maj 1969.

Rosendal, Niels Erik: "Ønsker dannet et kristeligt parti", Kristeligt Dagblad, 21. maj 1969. Rosendal, Niels Erik: "Grundprincipper for et kristeligt folkeparti", Kristeligt Dagblad, 7.-8. juni 1969.

usign.: "Billedporno fri fra 1. juli", Politiken, 29. maj 1969. 